\title{
IKZF3 Gene
}

National Cancer Institute

\section{Source}

National Cancer Institute. IKZF3 Gene. NCI Thesaurus. Code C80029.

This gene plays a role in both transcription in hematopoietic cells and lymphocyte development. 